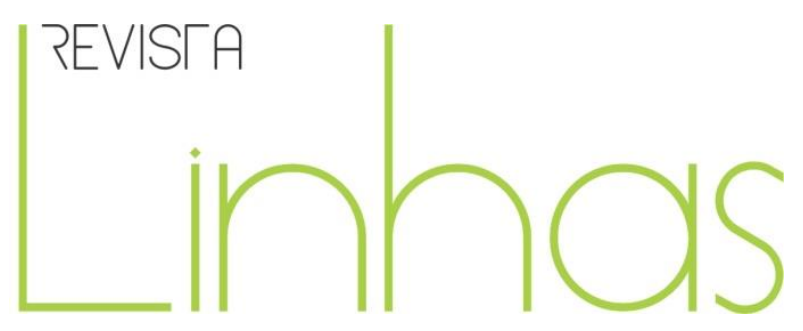

\title{
A inspeção da instrução pública na província de São Paulo $(1836-1876)$
}

\section{Resumo}

O artigo apresenta uma síntese documental do desenvolvimento da inspeção da Instrução Pública na Província de São Paulo entre 1836 e 1876, considerando o movimento de especialização no Governo da Província e a conformação da instrução pública baseada numa economia moral, financeira e política. O estudo adota a análise documental dos registros do executivo provincial tendo por fonte privilegiada o corpus formado pelos Relatórios dos Presidentes da Província de São Paulo destinados a Assembleia Legislativa Provincial no período, acompanhados de seus anexos, dentre os quais os relatórios da Instrução Pública a partir de 1852. A organização da instrução pública nas províncias do Império nesse corpus documental ampliado revela inspiração em modelos culturais de governança vindos de países da Europa e dos Estados Unidos da América do Norte. Na Província de São Paulo, o artigo destaca ainda a presença de Presidentes de Província beduínos em contraste com a permanência dos Inspetores Gerais apresentando, como hipótese, a descentralização da política de instrução pública no Império como artefato de indução da centralização dessas mesmas políticas.

Palavras-chave: Inspeção da Instrução Pública. Província de São Paulo. Século XIX.

\author{
Célia Maria Benedicto Giglio \\ Universidade Federal de São \\ Paulo - UNIFESP - São \\ Paulo/Brasil \\ celia.giglio@unifesp.br
}

\footnotetext{
Para citar este artigo:

GIGLIO, Célia Maria Benedicto. A inspeção da instrução pública na província de São Paulo (1836 - 1876).

Revista Linhas. Florianópolis, v. 18, n. 36, p. 64-95, jan./abr. 2017.
}

http://dx.doi.org/10.5965/1984723818362017064 


\title{
Public education inspection in São Paulo Province (1836-1876)
}

\begin{abstract}
This article presents a documental review of the development in Public Education inspection in São Paulo Province, from 1836 to 1876 , considering the compartmentalization movement that took place in the Government of that Province, and also the structuring of the Public Education based on the moral, financial, and political standards of the time. The study investigates the documental registers of the executive power of the Province, holding as privileged source the corpus made of Reports of the Presidents of the São Paulo Province sent to the Provincial House of Representatives during this period, together with its attachments, such as the Public Education Reports published as of 1852 . The Public Education in the Empire provinces, analyzed in this enlarged corpus, reveals that the educational organization was inspired by cultural models of governance originated in European countries and in the USA. This paper also highlights the existence of Bedouin Province Presidents (HAIDAR, 1972:29) in São Paulo, in contrast to the stability of the General Inspectors, and presents the hypothesis that the decentralization of the Public Instruction policy in the Empire was the fact that triggered the centralization of these same policies.
\end{abstract}

Keywords: Public Education Inspection. São Paulo Province. XIX Century. 
A investigação sobre 0 desenvolvimento das nascentes estruturas de administração da instrução pública no século XIX, após a independência, oferece ao pesquisador da educação um cenário documental privilegiado ao nos colocar diante de arquivos de documentos oficiais brasileiros que guardam relatórios ministeriais e relatórios presidenciais das províncias ${ }^{1}$, permitindo acompanhar tanto o processo de especialização do Estado, com o desenvolvimento de suas instituições, quanto o conjunto de estratégias de governo destinadas a civilizar e pacificar as populações.

Temos nesse corpus documental pelo menos duas vias de investigação: por meio da busca no interior das fronteiras do que se convencionou como instrução pública, e outra, que interroga as relações sociais e institucionais expressas nesses documentos que podem dar visibilidade a demandas que conformam o campo da instrução pública, revelando a condensação de expectativas da sociedade política da época sobre os modos de civilização necessários ao governo do império e das províncias.

A escolha dessa segunda via, apesar do labirinto documental que impõe pela exigência de uma leitura extensa e atenta, permite acompanhar uma teia de vozes e um emaranhado de acontecimentos que revelam a possibilidade de percepção do movimento de fabricação do Estado, de suas estruturas, das contradições e dependências materializadas nesses textos que, longe de constituírem-se em modelos tediosos de narrativas que se repetem, revelam uma face do processo de governo ${ }^{2}$. É partindo dessa escolha que, aqui, apresentamos uma síntese documental do desenvolvimento da inspeção da Instrução Pública na Província de São Paulo entre 1836 e 1876, considerando o movimento de especialização no Governo da Província e a conformação da instrução pública baseada numa economia moral, financeira e política.

\footnotetext{
${ }^{1} \mathrm{O}$ Latin American Microform Project (LAMP) no Center for Research Libraries (CRL) produziu imagens digitais de séries de publicações emitidas pelo Poder Executivo do Governo do Brasil entre 1821 e 1993, e pelos governos das províncias, desde as mais antigas, disponível para cada província até o fim do Império em 1889. O projeto proporciona acesso via Internet aos documentos, facilitando assim a sua utilização por pesquisadores e prestando apoio às pesquisas latino-americanas nesta iniciativa patrocinada no hemisfério pela Fundação Andrew W. Mellon. <http://www-apps.crl.edu/node/2>.

${ }^{2}$ Sem secundarizar os muitos e importantes estudos históricos sobre o período, nosso objetivo nesse estudo é o de acompanhamento ao desenvolvimento das práticas de governo da instrução pública no interior da massa discursiva contida nesse arquivo.
} 
Ao privilegiar a inspeção da instrução pública, abordaremos a arquitetura dessa prática administrativa em dois tempos: o do governo da Instrução Pública pelo presidente da Província de São Paulo, de 1834 a meados de 1850, e outro a partir da instalação da Inspetoria Geral da Instrução Pública como parte do movimento de especialização no interior do governo. A diferença entre os dois períodos advém dessa especialização, que mostra o movimento de racionalização do campo da instrução pública e ensaia ações que tensionam as políticas da instrução como políticas de Estado em contraposição ao modelo patrimonialista de governo da província.

\section{O desenvolvimento da inspeção da Instrução Pública na Província de São Paulo entre 1836 e 1876}

Uma análise global dos relatórios dos presidentes de província permite verificar que o instituto da inspeção nos governos provinciais e no governo central durante o século XIX tem suas origens numa prática política de controle dos negócios do Estado em todos os âmbitos da administração pública; tendo em vista que a administração e suas instituições se encontram em desenvolvimento no contexto da recém-independência, da consolidação da Constituição do Império e da autonomia para legislar conferida às províncias em 1834, a inspeção corresponde ao grau de especialização e normatização de cada ramo dos negócios da província.

Essa correspondência está associada ao duplo movimento existente entre normas prescritivas escritas e ação direta executada por meio da vigilância e realizada por agentes do Estado, sendo, portanto, uma prática que se desenvolve de modo complementar, com a finalidade de produzir efeitos práticos a partir dos textos dessas prescrições, fato que revela uma prática cultural instituinte para o período.

Chartier (1990, p. 218), ao tratar da construção do Estado moderno na Europa ocidental e das formas culturais que caracterizam este Estado, aborda a presença da escrita, apresentando três grandes rupturas na forma como o Estado dá a conhecer as suas vontades ou registra a de seus súditos: a que substitui a declaração oral pela fixação escrita, a que substitui o recurso ao notário pelo desenvolvimento das chancelarias e a que faz recuar o manuscrito perante o texto impresso. 
Esta última ruptura oferece uma chave de entrada importante para pensarmos a proliferação de ordens, leis, regulamentos e prescrições de práticas de governo presentes entre nós durante o século XIX e as correspondentes demandas de leitura e escrita de seus agentes desde o Estado. Este recuo do manuscrito em favor dos textos impressos, segundo Chartier (1990), altera a escala de circulação dos documentos oficiais e dos demais escritos.

A produção escrita do Estado imperial brasileiro pode ser considerada um artefato da cultura governamental que dá visibilidade ao processo de institucionalização de mecanismos de poder nos quais as maneiras de ler e os modos de escrever assumem funções inequívocas de construção e manutenção da ordem instituída. Reencontrar as práticas de leitura na espessura destes artefatos culturais de governo indica um necessário retorno aos impressos com um itinerário específico que possibilite interrogar os textos no sentido proposto por Chartier quanto às competências culturais dos agentes aos quais se destinam, mas também atento às tensões e subversões reveladas pelos próprios textos.

Acompanhando a produção sistemática de relatórios dos governos provinciais, podemos afirmar que a circulação dos impressos produziu também a circulação de modelos de registros que construíram espécies de protocolos de comunicação e de transmissão de informações escritas que viabilizaram organizar um saber muito caro aos governos: as estatísticas.

A circulação dos impressos permitiu a uniformidade dos registros e a divulgação e transferência de saberes da administração do estado tanto no interior do império quanto no plano internacional. Exemplos dessa circulação podem ser conferidos a partir do estudo comparado de documentos governamentais que possuíam a mesma função em outros países da América Latina e na Europa ${ }^{3}$. De outra parte, ao uniformizar práticas de

\footnotetext{
${ }^{3}$ Tivemos a oportunidade de analisar relatórios de presidentes de províncias no Chile e em Portugal que apresentam o mesmo regime de organização interna que inspira nossos relatórios; outro indício dessa circulação pode ser encontrado nos próprios relatórios de províncias brasileiras ao citarem experiências de governo em outros países, tomando-as muitas vezes como modelos inspiradores. Não raro é possível também verificar em alguns relatórios comentários, citações ou até a cópia de trechos de relatórios de outras províncias, o que demonstra que esses impressos tiveram também a função de induzir internamente modelos de governo, vulgarizando não apenas ideários políticos e práticas administrativas, mas também as teorias. A construção da casa de Correção da Província, fundada pela Província em 1834, é exemplo claro do movimento de constituição de um saber especializado. No âmbito da instrução pública são muitos os
} 
registro, induz-se também as práticas de governo que passam a dar visibilidade e conformar os objetos que são o alvo do governo.

Desse modo, é relevante considerar que a inspeção da instrução pública é uma variante do modelo de governo dos negócios do Estado não apenas durante o século XIX. Os inspetores, de modo geral, tinham a seu encargo a tarefa de induzir, vigiar, corrigir e fazer cumprir os dispositivos reguladores, sejam eles as leis, regulamentos ou outras normas emanadas do governo, e o faziam nesse duplo movimento: a partir das normas escritas exerciam autoridade por meio da presença, observação e registros, e ao reunir informações advindas da observação, forneciam elementos para a produção de novas normas e a revisão das já existentes, de modo a cobrir as subversões observadas, gerando as condições para o desenvolvimento de uma nova tecnologia de governo que permitiu cada vez mais estabelecer vinculações entre os diferentes ramos da administração e especializar suas ações.

A inspeção está inscrita numa fórmula mais geral de civilização que articula o olhar à palavra - às leis, normas, regulamentos -, e a palavras às ações ou práticas de governo. O longo curso de implantação dessa racionalidade demonstra a demanda pela organização de um corpo de funcionários do Estado que com as precisas qualidades e independentes das relações de fidelidade, ampliem a presença do poder de Estado.

A estatística foi a tecnologia, a sciencia dos factos sociaes, que permitiu ao governo conhecer em nova escala o seu território, tornando-se a inspeção um meio imprescindível, a forma complementar à norma para dar uniformidade às condutas dos agentes públicos e aos registros necessários a essa estatística. Em cada ramo dos negócios da província há a presença da inspeção e de inspetores em toda a arquitetura de governo. A prática da inspeção estabelece uma nascente rede de informantes, levando a um processo de diferenciação crescente tanto das ações de seus agentes quanto dos padrões de observação, classificação, formas de registro, protocolos, dentre outros. José Thomaz Nabuco D’Araújo, Presidente da Província de São Paulo, traduz essa necessidade à Assembleia Provincial em 1852:

exemplos citados de outros países, predominando até os inícios de 1870 a França e depois a América do Norte. 
Como se pode legislar e administrar sem uma Estatística? No exercício de vossas funções importantes sentireis a mesma dificuldade, que, como administrador, tenho sentido, embaraçado a cada passo pela ignorância dos factos, os quais alias registrados, comparados, observados e moralizados habilitarão para legislar e administrar com certeza, e não vagamente, com conhecimento de causa, e não por informações fundadas em dados, que pela ansiedade e urgência da ocasião são mal coligidos, falsos ou inexatos. ${ }^{4}$

As coisas sobre as quais a estatística incidia demarcavam um campo de resistências, conflitos e outros eventos que era preciso dominar, conhecer para regulamentar. A população existente precisava ser recenseada, classificada por sexo, idade, estado, condição, naturalidade, profissão; saber que doenças a afetavam, o comportamento das epidemias, a quantidade de loucos e leprosos que vagavam pelas cidades, o número de mortes e suas causas; os negócios solicitavam saber quantas fazendas, o que produziam, quanto gado existia, número de escravos, colonos, animais, quanto a província exportava, quanto importava; quantas eram as escolas públicas, privadas, sua população, quantos mestres, qual seu ordenado; quantos guardas existiam, quantos conventos, confrarias, casas de recolhimento, capelas, qual era o número do clero secular, onde estavam empregados, onde residiam. Era preciso saber qual a influência das instituições sobre a vida dos cidadãos, conhecer os eventos que envolviam a população e o interesse do Estado através da investigação estatística.

Na organização da administração da justiça e da força pública, a figura dos Inspetores surgiu na hierarquia da polícia, desde 1827 , como oficiais de quarteirão e, a partir do código de processo Criminal do Império, em 1832, como inspetores de quarteirão, considerados como uma autoridade na porta das casas ${ }^{5}$. Esse agente, além

\footnotetext{
${ }^{4}$ Discurso com que o llustríssimo e Excelentíssimo Senhor Dr. José Thomaz Nabuco D’Araújo, Presidente da Província de São Paulo, abriu a Assembleia Legislativa Provincial, no $1^{\circ}$ de maio de 1852.

${ }^{5}$ Sobre o assunto, veja-se Wellington Barbosa da Silva "Uma autoridade na porta das casas": os inspetores de quarteirão e o policiamento no Recife do século XIX (1830-1850). SAECULUM [17]; João Pessoa, jul./ dez. 2007. P.27-41. Em São Paulo o Regulamento $n^{\circ}$ 120, de 1841 instituiu a figura do Inspetor de quarteirão como autoridade na garantia da paz pública, que perdurou na república. Veja-se o Decreto $n^{\circ} 6.746$, de 16 de setembro de 1975, de São Paulo, que regula a função: Governo do Estado de São Paulo Reorganiza a função de inspetor-de-quarteirão: Artigo $2^{\circ}$ - A função de inspetor-de-quarteirão, exercida a título gratuito, é considerada relevante e tem por finalidade auxiliar a atividade policial.
} 
das tarefas que assumia de velar pela tranquilidade pública em sua área de responsabilidade, fazia parte de uma cadeia regular e sistemática desde o Chefe de polícia até o Inspetor de Quarteirão responsável também pela formação de uma estatística criminal na província ${ }^{6}$.

A presença de inspetores pode ainda ser encontrada na área das obras públicas e outros ramos do governo e são frequentes ainda as Comissões Inspetoras, previstas em regulamentos ou nomeadas de modo extraordinário, com características itinerantes que atuaram com focos específicos e objetivos definidos, em geral de exame e verificação do estado das instituições para dar contas deles sobre sua utilidade para a Província, ou ainda com características de diligências para a realização de investigações. O status conferido à observação possibilita a invenção de fórmulas que se aproximam a de uma pirâmide de olhares capaz de funcionar como modelo de vigilância. Esboça-se, assim, a crescente racionalização das estratégias de controle do Estado, conformando a própria disposição espacial e social dos indivíduos, ao objetivo de submeter todos a uma única vigilância.?

Este modelo de organização piramidal de controle e a introdução de novas técnicas para a obtenção de informações em escala ampliada, será reproduzido em outras instâncias da administração. Enquanto a manutenção da tranquilidade pública se materializa numa trama de controles policiais e no uso de novas técnicas de registro e

\footnotetext{
${ }^{6}$ Discurso Recitado pelo Exmo. Presidente José Carlos Pereira d'Almeida Torres 7.1.1843, por ocasião da abertura da Assembleia Legislativa da Província de S. Paulo.

${ }^{7}$ Foucault (1983, p. 103-7), ao tratar do nascimento do Panoptismo e suas relações com a teoria do Direito Penal, entre os séculos XVIII e XIX, justifica suas teses lançando mão de autores do início do século XIX que refletiram sobre as transformações na "organização da penalidade ou da moral estatal"; cita como exemplos: Giulius que, em 1830, publicou um tratado chamado Lições sobre as Prisões e Treilhard, conselheiro de Estado, na apresentação do Código de Instrução Criminal de 1808. No primeiro, se encontra uma passagem em que Giulius compara a arquitetura da civilização grega, que tinha como preocupação central o problema de como possibilitar o espetáculo de um acontecimento ao maior número de pessoas, para o problema fundamental da arquitetura moderna, cuja preocupação central se coloca em termos de como fazer com que o maior número de pessoas seja oferecido como espetáculo a um só indivíduo encarregado de vigiá-las. Afirma Foucault que Giulius estava pensando no Panóptico de Benthan, que se referia a uma arquitetura da vigilância. Quanto ao segundo exemplo, destaca que o próprio Código funciona como um Panóptico, dando ao procurador um papel completamente novo. Afirma Foucault que o procurador, no Código, surge como aquele que, além de agir quando a lei é violada, é antes de tudo um olhar, um olho perpetuamente aberto sobre a população. "O olho do procurador deve transmitir as informações ao olho do Procurador Geral que, por sua vez, as transmite ao grande olho da vigilância que era, na época, o Ministro da Polícia. Este último transmite as informações ao olho daquele que se encontra no ponto mais alto da sociedade, o imperador que, precisamente na época, era simbolizado por um olho. (...) Olho auxiliado por uma série de olhares, dispostos em forma de pirâmide a partir do olho imperial e que vigiam toda a sociedade."
} 
observação em relações hierarquizadas, a Instrução Pública organiza o aparato de inspeção e controle sobre as escolas, sobre as matrículas, as práticas dos mestres e os comportamentos dos alunos e suas famílias.

O movimento de formação de uma estatística da instrução pública no século XIX foi internacional e pode ser conhecido pelo estudo comparado dessas fontes que apresentam, inclusive, iniciativas europeias de levantamento de dados para a confecção de um Mapa Mundi da Instrução Popular em 1880.

O estudo do governo da Instrução Pública na Província de São Paulo cobre os inícios da organização do campo educativo que reflete as mudanças na organização político-administrativa da Província e o complexo movimento de institucionalização de práticas civilizatórias traduzidas na fabricação de um conjunto de instituições destinadas a instruir, corrigir, curar e punir.

Ao percorrermos os discursos contidos no conjunto dos relatórios que tomam por objeto a ignorância - seja a do povo ou das elites -, identificamos demandas dirigidas à instrução pública enunciadas por diferentes agentes do governo, especialmente pela polícia, vinculando a educação e a instrução aos meios tanto de correção e regeneração dos indivíduos, quanto de prevenção da criminalidade; outras partem da esfera do direito, de uma ordem jurídica que se manifesta nas formas de bem viver, da obediência às leis, aos preceitos de moralidade e religiosidade, de respeito à autoridade. Por fim, encontramos enunciados que partem de lugares distintos, que têm em vista a preservação da vida por meio do aprendizado de uma conduta higiênica, da superação de preconceitos que causam a morte da população e que justificam, cada vez mais, a invasão do Estado na vida dos cidadãos: a obrigatoriedade da vacina, a obrigatoriedade à instrução escolar das crianças, a formação nos ofícios e indústrias para os órfãos, o resgate dos menores vadios para as colônias orfanológicas para aprenderem a ser úteis a si e à sociedade.

Estes espaços que se imbricam com a instrução pública, acenam o emaranhado das fronteiras existentes entre as práticas educativas disseminadas nas instituições e nas medidas legais que envolvem todo o corpo social, por meio da normalização da sociedade. Desse modo, é importante considerar que esse ramo da administração se desenvolve em total cumplicidade com os demais. O recorte desse corpus documental a 
fim de dar relevo às práticas da inspeção da instrução pública não perde de vista que o conjunto de relatórios descreve uma arte de governar que produz a visibilidade de uma série de espaços de governo: das famílias, das instituições, da população, do Estado; os relatórios falam do processo de organização da sociedade para o estabelecimento de uma regularidade nos comportamentos a fim de a manter a ordem pública. A política, a economia, a população - enquanto alvos do governo -, surgem tendo como panorama a Província, a cidade e vilas ${ }^{8}$. A cidade, vista como espaço que delimita uma multiplicidade, engendra suas instituições num movimento contínuo; a cidade comporta o caos: vadiagem, mendicância, ócio; ao redor da cidade vagam os leprosos com seus andrajos, espalhando a ameaça e o medo; a população pobre, na cidade, se transforma em classe perigosa que é preciso tutelar. Na cidade, a noite se transforma em escuridão, treva da imoralidade, esconderijo do crime. Da instauração da nova ordem de governo na província se organiza um corpo jurídico e seus agentes em garantia da execução das leis; um corpo policial e o aparato de repressão, a necessidade da correção. A educação e a instrução se desenvolvem nesse panorama, imbricada com os demais ramos de atuação pública do Estado.

\section{O governo da Instrução Pública pelo Presidente da Província de São Paulo (1836 a 1850)}

A organização dos governos provinciais foi instituída pela Lei Geral de 20 de outubro de 1823 que criou, em cada Província, um cargo de Presidente, de nomeação do Imperador, "amovível quando conveniente, sendo o executor e administrador da província e por ela estritamente responsável", e um Conselho composto de seis membros eleitos, dentre eles um Vice-Presidente destinado a substituí-lo, tanto quanto os demais conselheiros na impossibilidade de fazê-lo o vice-presidente. Ao Conselho cabia propor e deliberar sobre questões relativas à infraestrutura da Província e, dentre os objetos destinados ao exame e juízo desse Conselho estão: promover a educação da mocidade; vigiar os estabelecimentos de caridade, prisões e casas de correção e trabalho; propor o estabelecimento de Câmaras onde as deve haver; formar censo e estatística da Província.

\footnotetext{
${ }^{8}$ À época, a Província possuía apenas uma cidade, São Paulo, e 45 municípios com status de vila, incluindo seis pertencentes ao Paraná que, até 1853, era parte do território da Província de São Paulo (CALIMAN, 1999, p. 14).
} 
A organização política foi estabelecida pela Constituição Política do Império, de 25 de março de 1824 que instituiu Conselhos Gerais Provinciais e Câmaras em todas as Cidades e Vilas, a serem eleitos com regularidade e tendo por principal objeto "propor, discutir e deliberar sobre os negócios mais interessantes de suas Províncias, formando projetos peculiares e acomodados às suas localidades e urgências". Conforme Oliveira (2015, p. 94), essas atribuições possuíam característica singular "que não se atinha propriamente à esfera provincial, mas à municipal. Tratava-se do controle exercido pelos Conselhos Gerais sobre as atividades desenvolvidas pelas Câmaras Municipais". Pelo artigo 83 da Constituição do Império, os Conselhos Gerais não podiam propor, nem deliberar sobre interesses gerais da nação, sobre as relações com outras Províncias, sobre a proposição e execução de Leis, cabendo à Assembleia Geral Legislativa deliberar soberanamente sobre as matérias.

Incontornável, essa dupla subordinação - à Assembleia Geral e ao Executivo - balizava o alcance político do novo órgão: aos Conselhos Gerais não caberia legislar, mas sim propor matérias que, revertidas em projetos de lei, teriam que necessariamente passar pelo poder decisório dos legisladores e do governo central. (OLIVEIRA, 2015, p. 93-4)

O Ato Adicional de 1834 à Constituição Política do Império, Lei $n^{\circ} 16$ de 12 de agosto de 1834, modifica sobremaneira a condução político administrativa das Províncias. Substitui os Conselhos Gerais instituídos pela Lei de 20 de outubro de 1823, estabelecendo em seu lugar as Assembleias Legislativas Provinciais às quais competia legislar, dentre outras matérias, "sobre instrução pública e estabelecimentos próprios a promove-la, não compreendendo as faculdades de Medicina, os Cursos Jurídicos, Academias atualmente existentes e outros quaisquer estabelecimentos de instrução que para o futuro forem criados por lei geral" ( $\left(2^{\circ}\right.$ Art. 10).

A Província de São Paulo procede à primeira eleição para a Assembleia Legislativa Provincial em 1835 e a instala em 2 de fevereiro de 1835, junto ao Palácio do Governo, no Pátio do Colégio, lugar onde permaneceu até 1879. Nessa nova dinâmica, o Ato Adicional de 1834 determinava: 
Art. $8^{\circ} \mathrm{O}$ Presidente da Província assistirá a instalação da Assembleia Provincial, que se fará, à exceção da primeira vez, no dia que ela marcar terá assento igual ao do Presidente dela, e à sua direita; e aí dirigirá à mesma Assembleia a sua Fala, instruindo-a do estado dos negócios públicos, e das providencias, que mais precisar a Província para seu melhoramento.

A primeira Fala dirigida à Assembleia Provincial data de 7 de janeiro de 1836 pelo Presidente José Cezario de Miranda Ribeiro. Os textos resultantes dessas Falas são nomeados como discursos ou relatórios até o final do Império. A ocorrência dos relatórios da presidência, além de marcar a abertura das sessões legislativas a cada ano, aparece também nos momentos de passagem da presidência aos vice-presidentes que compõem o conselho ao longo de um mesmo ano legislativo.

Até o ano de 1850 as notícias sobre o estado da instrução pública são relatadas de modo a ter em destaque o estado não lisonjeiro desse ramo de serviços na província. Numa breve descrição desses relatos é possível registrar um conjunto de problemas que apontam a necessidade de aperfeiçoamento dos modos de inspeção como solução e condição de melhoramento da instrução.

Algumas das questões centrais narradas nesses primeiros relatórios, considerando as escolas de primeiras letras, dizem respeito à falta de precisão no número de meninos que frequentavam as escolas, uma vez que as informações vinham diretamente dos professores, que segundo o presidente, não eram confiáveis. O comportamento dos professores, relativamente à moral e ao ensino, somado à incúria dos pais para enviar e manter seus filhos nas escolas são problemas narrados de modo recorrente; do mesmo modo é lançada dúvida sobre a inspeção das aulas que deveria ser realizada pelas Câmaras Municipais:

... duvido que a inspeção das aulas menores seja devidamente feita pelas Câmaras Municipais que a têm a seu cargo. Para demonstrar-vos, até que ponto estas Corporações, a despeito de toda honradez e louváveis sentimentos de seus Membros, são impróprias para essa inspeção, citarvos-ei o fato de uma Câmara que, denunciando antigos desleixos de um Professor, confessou francamente que por muito tempo os havia ignorado, porque seus Membros moravam todos fora da Vila, e quando se reuniam em sessão ordinária, o Professor era então, mas só durante os poucos dias da sessão, muito assíduo e exato no cumprimento de seus deveres, de maneira que a Câmara muito conscienciosamente, e segundo 
a própria evidência, dava-lhe os necessários atestados para a cobrança de seus ordenados, apesar de todo resto do ano ele viesse na maior relaxação e escândalo, sem curar absolutamente de seus alunos. (...) a ação do Governo não pode suprir essa fiscalização a cargo das Câmaras, pois que além do quanto é remota dos lugares onde se deve exercer, é também ineficaz por limitada $(1840)^{9}$

O relatório do presidente apontava como forma de superar as limitações, a constituição de Comissões inspetoras locais ou Comissões de Distritos em substituição à inspeção feita pelas Câmaras, inspirado na experiência do sistema de inspeção francês:

Inspetores singulares para certos círculos, que visitassem as escolas, e informassem o Governo, preencheriam de certo melhor as vistas do legislador; e a única coisa que invejo dessas Comissões no sistema da França é o entrarem na composição delas os Párocos, porque entendo, Senhores, que a parte religiosa deve predominar muito na educação, de nós espera a geração nascente. (1840). ${ }^{10}$

A pouca concorrência de alunos às escolas em lugares populosos e o pouco adiantamento deles são identificados como resultado da negligência ou inaptidão dos professores. As atribuições do governo para interferir, chamando à responsabilidade os negligentes ou incapazes, segundo o presidente em 1843, eram narradas como ineficazes, tanto pela improbidade dos corpos coletivos na inspeção imediata das aulas, quanto pela ausência de mecanismo que assegurasse a correção dos professores e, para tanto, o presidente apresentou à Assembleia, naquele ano, a necessidade de dar-se ao Governo o poder de demitir os professores. ${ }^{11}$ O processo para solucionar os problemas morais ou de aptidão dos mestres não atendia a urgência dos fatos e, em 1845, mais uma vez essa demanda se apresentou à Assembleia:

O retardamento do Governo Provincial em demitir de pronto e sem dependência de processo de responsabilidade os Professores que aberrarem de seus deveres, não me parece consentâneo: ao menos a experiência o tem mostrado. Se as Câmaras Municipais inspecionam e a

\footnotetext{
${ }^{9}$ Discurso recitado pelo Exmo. Presidente, Manoel Machado Nunes no dia 7 de janeiro de 1840.

${ }^{10}$ Idem.

${ }^{11}$ Discurso recitado pelo Exmo. Presidente, José Carlos Pereira d'Almeida Torres, no dia 7 de janeiro de 1843.
} 
Presidência possui as relações de alunos com as necessárias observações, o cálculo e as imediatas medidas devem ser confiadas à ação da Presidência, ouvindo as Câmaras. Um processo de responsabilidade demanda tantas formas e tergiversações, que as mais das vezes o Juiz sente-se compelido a julgar pelas formas não pela convicção; acontecendo de aqui retomar à Cadeira quem é incapaz de a reger em prejuízo da instrução pública. Urge pois que legisleis a respeito, como julgardes convinhável. $(1845)^{12}$

A formação da estatística da instrução, apresentada sistematicamente nos relatórios, é dependente da ação fiscalizadora das Câmaras e, em 1844, o presidente afirma que os números não devem ser exatos em razão das Câmaras transferirem suas responsabilidades da inspeção a fiscais e afirma: “... e vós sabeis qual seja, em geral, a qualidade e capacidade mental dos Fiscais nesses Municípios centrais". ${ }^{13}$

Em resposta às demandas dos presidentes, a Assembleia editou a Lei Provincial $n^{\circ}$ 34, de 16 de março de 1846, que regulamentou a instrução primária e o estabelecimento de escolas. Além de prescrever o currículo, as matérias de ensino, regulou a forma de estabelecer as escolas no território, as habilitações requeridas dos professores, as formas de provimento, vencimentos, e um conjunto importante de medidas que enquadraram suas responsabilidades e as punições previstas a eles para a correção, incluindo aí a demissão pelo Governo:

Da suspenção, remoção, e demissão dos professores públicos.

Art. 19. - Os professores públicos poderão ser suspensos pelo governo:

$\S 1_{1}^{\circ}$ - No caso de pronuncia por crime inafiançável em quanto durarem os seus efeitos.

$\S 2 .^{\circ}$ - Quando o governo lhes mande instaurar processos por crime de responsabilidade. A suspensão em todo o caso priva ao professor de todo, ou de parte do ordenado, durante o tempo dela, como determinar o governo.

Art. 21. - Os professores serão demitidos pelo governo.

$\S 1^{\circ}$ - Quando o requeiram, não havendo inconveniente, não tendo então lugar a aposentadoria.

$\S$ 2. $^{\circ}$ - Quando razões fundadas de moralidade assim o exijam a requerimento de qualquer autoridade, ou chefes de família, ouvidos o professor inculpado, e a comissão inspetora.

\footnotetext{
${ }^{12}$ Relatório apresentado pelo Exmo. Presidente Manuel da Fonseca Lima e Silva, no dia 7 de janeiro de 1845.

${ }^{13}$ Discurso recitado pelo Exmo. Presidente, Manuel Felisardo de Souza e Mello, no dia 7 de janeiro de 1844.
} 
$\S 3 .^{\circ}$ - Quando depois de advertidos ou multados por três vezes se mostrem incorrigíveis, ou quando desobedeçam formalmente às ordens do governo, dependendo neste último caso de aprovação da assembleia provincial.

$\S 4 .^{\circ}$ - Quando forem condenados por furto, roubo, juramento falso, ou falsidade.

$\S 5 .^{\circ}$ - Quando por motivo de enfermidades tornem-se inábeis, salva a disposição do artigo dezoito.

$\S 6 .^{\circ}$ - Quando por culpa sua forem as escolas frequentadas por menos de doze alunos efetivos. ${ }^{14}$

A mesma Lei atendeu aos pedidos dos presidentes quanto a necessidade de estabelecer um novo modelo de inspeção na Província, que assumiu a inspiração francesa apresentada em 1840; definiu as competências das Comissões inspetoras e impôs a inspeção delas pelo governo, prevendo medidas corretivas que previam multas por negligência e até a dissolução das comissões pelo governo.

Da inspeção das escolas, e exame dos alunos.

Art. 25. - Haverá em cada povoação, onde houver escola pública ou particular, uma comissão composta de três cidadãos residentes no lugar, um nomeado pelo governo, e dois pela câmara municipal, sendo um sacerdote, o qual poderá ser o pároco.

Art. 26. - A esta comissão compete:

$\S \mathbf{1 .}^{\circ}$ - Inspecionar as escolas públicas e particulares estabelecidas nas povoações de sua residência, fazendo ao menos uma visita mensal.

§ 2. ${ }^{\circ}$ - Verificar o número dos alunos que frequentam efetivamente a escola.

$\S 3 .^{\circ}$ - Examinar a salubridade do local das escolas, e se nelas se ensinam regularmente as matérias conforme a presente lei, e se os professores cumprem tudo quanto for determinado nos regulamentos e instruções.

$\S$ 4. - Enviar trimestralmente ao governo uma informação circunstanciada do estado das escolas, do progresso dos alunos, das causas da falta de concorrência, quando se realize, e de todas as necessidades que ocorrerem.

$\S 5 .^{\circ}$ - Assistir aos exames anuais dos alunos na época determinada.

$\S 6 .^{\circ}$ - Fazer aos professores advertências sobre omissões leves no cumprimento de seus deveres, participando ao governo quando se mostrem incorrigíveis, comunicando também todas as faltas que encontrarem.

$\S 7 .^{\circ}$ - Exigir dos professores nas visitas que fizerem, todos os esclarecimentos que julgarem precisos, para basearem suas informações;

14 Lei $\mathrm{n}^{\circ} 34$ de 16 de março de 1846. <http://www.al.sp.gov.br/repositorio/legislacao/lei/1846/lei-3416.03.1846.html>. 
e na época marcada um mapa dos alunos segundo as instruções do governo.

$\S 8 .^{\circ}$ - Dar atestados aos professores para cobrarem seus vencimentos; declarando neles o número de alunos que efetivamente frequentam as escolas.

Art. 27. - Quando os professores abandonarem o exercício do emprego, e estiverem impedidos, havendo probabilidade de durar o impedimento por mais de um mês, as comissões inspetoras (caso não haja substituto aprovado) poderão contratar quem seja as escolas provisoriamente, percebendo dois terços dos vencimentos.

Art. 28. - As comissões inspetoras poderão deliberar, reunidos dois membros, quando o terceiro esteja impedido, e o que for nomeado pelo governo terá a seu cargo todos os papeis relativos à incumbência delas, e em seu nome dirigirá a correspondência.

Art. 29. - O governo, mostrando-se as comissões inspetoras negligentes ou omissas, poderá multa-las, ou a seus membros individualmente em dez a trinta mil réis; e também dissolvê-las organizando novas, excluindo alguns ou todos os membros das que dissolver. ${ }^{15}$

Ao mesmo tempo em que a inspeção da instrução pública é concebida como imprescindível, a prática da inspeção se apresenta como um desafio a ser suplantado. É no quadro dos desafios de administrar a instrução pública que o modelo de inspeção se desenvolve, com a finalidade de estender o poder de Estado, fazendo cumprir as regras e normas que regem a instrução pública, fundando uma mecânica que pretendeu dominar duas ordens de problemas que exigiram a adoção de medidas diferenciadas: a inspeção do governo das instituições cerradas - dentre as quais estão os Seminários de Educandos -, e do governo das escolas de primeiras letras, dispersas no território, em que o governo era o do Professor.

O governo do Seminário de Educandos e o Seminário de Educandas, filhos e filhas adotivos da Província, foi traçado por Regulamentos editados pelo Presidente em 1845, e prescreviam as formas de ingresso e retirada dos educandos, a organização interna das casas, regulando inclusive a economia dos castigos a serem aplicados; normatizam disposições diversas: estabelecem o perfil dos diretores, dos professores, as condições que impunham a demissão destes empregados, a forma de escrituração, o regime instrutivo e econômico da casa e a forma de sua inspeção:

\footnotetext{
${ }^{15}$ Idem.
} 
Art. $2^{\circ} \mathrm{O}$ Seminário é sujeito a autoridade e inspeção do presidente da Província, que o visitará a miúdo, examinando por si ou por meio de Comissão de que trata o Art. 34 destes Estatutos, o regime instrutivo e econômico, que por estes for prescrito (...)

Art. 34 Um mês antes da abertura da Assembleia Legislativa Provincial, o Presidente da província nomeará uma Comissão de três Membros para tomar conhecimento do estado do Seminário, e dar à Presidência as informações precisas para serem levadas ao conhecimento da mesma Assembleia. À Comissão cumpre o seguinte:

$1^{\circ} \mathrm{O}$ exame da administração geral e particular do Estabelecimento, se é ela conforme no disposto nestes Estatutos, e sobre a escrituração respectiva.

$2^{\circ} \mathrm{A}$ inspeção sobre a capacidade intelectual dos Empregados no ensino moral, religioso e instrutivo das Educandas, sobre a prática seguida neste ensino, e sobre o estado de aproveitamento dos ramos que formam a educação das mesmas Educandas.

$3^{\circ}$ Conhecer do tratamento e regime econômico empregado para com as Educandas.

$4^{\circ}$ Formar contas ao Síndico da receita e despesa dos fundos patrimoniais do Seminário, exibindo este o respectivo Livro e os documentos à que ele se referir. (Regulamento para o Seminário das Educandas desta Imperial Cidade de São Paulo 1845) $)^{16}$

O governo da Casa de Educação dos Meninos Pobres da Imperial Cidade de São Paulo, conhecido como Seminário de Educandos, conforme seu regulamento, foi feito diretamente pelo presidente da província, coadjuvado por um Diretor imediato, não havendo, portanto, menção à inspeção dado que essa tarefa foi incumbida diretamente ao presidente:

Art. $1^{\circ}$ O Presidente da Província será o Diretor nato deste Estabelecimento, deverá visitá-lo algumas vezes para que possa conhecer pessoalmente de sua administração, do progresso instrutivo dos Educandos, e da capacidade e eficácia do Diretor econômico; receberá as contas trimestrais e orçamentos, e, além disso, as informações que exigir, para que possa ter o mais cabal conhecimento da Casa; e em seu relatório à Assembleia legislativa Provincial exporá circunstanciadamente tudo quanto for relativo à este Estabelecimento, e com especialidade concernente ao seu aumento, e à comodidade dos Educandos.

Art. $2^{\circ} \mathrm{A}$ Casa será regida imediatamente por um Diretor, que deverá ser da nomeação do Presidente da Província, e amovível, conforme os

\footnotetext{
${ }^{16}$ Regulamento para a Casa de educação dos meninos pobres da Imperial Cidade de São Paulo. Anexos ao Relatório apresentado a Assembleia Legislativa Provincial de São Paulo pelo Exmo. Presidente da mesma província, Manuel da Fonseca Lima e Silva, no dia 7 de janeiro de 1845.
} 
interesses do Estabelecimento. Este cargo recairá em indivíduo que tenha a necessária idoneidade para reger e inspecionar a Casa, e administrar o seu econômico com zelo, e discrição, sendo preferido o que for casado. (...) (Regulamento para a Casa de educação dos meninos pobres da Imperial Cidade de São Paulo 1945) ${ }^{17}$

Os regulamentos e a direção dada a esses estabelecimentos organizaram um modo de inspeção que permitiu acompanhar, com regularidade, seus desenvolvimentos e as mazelas que envolviam a administração dessas instituições, em que a instrução é apenas uma parte do cotidiano. Ao acompanhar a narrativa do estado dos Seminários, verificamos que a inspeção envolve o cuidado da vida dos educandos em todos os seus aspectos e, de modo especial, a busca de soluções para a saída deles ao atingirem certa idade, de modo a serem úteis a si e à sociedade. Nesse sentido, são tratados como filhos da província, tendo lugar de destaque o destino a ser dado às mulheres. ${ }^{18}$

O governo das escolas de primeiras letras e os desafios para a inspeção delas, apesar da Lei de 1846, teve maior centralidade a partir da criação da Repartição da Instrução Pública e a apresentação do estado da instrução pelos presidentes à Assembleia, a cada ano, passou a qualificar com maior exatidão os problemas, dando visibilidade às interdependências e complexas relações envolvidas na organização desse ramo da administração.

\section{O governo da Instrução Pública a partir da criação da Repartição da Instrução Pública de São Paulo (1850 a 1876)}

O período que segue aos anos de 1850 para o campo da instrução pública é inicialmente de grande entusiasmo, tanto pelo melhoramento da instrução em razão da maior autonomia do governo provincial para dar regulamentos ao ensino, quanto pela instalação da Repartição da Instrução Pública, ordenada pelo Regulamento de 8 de novembro de 1851, que organizou tanto a Inspetoria Geral quanto as inspetorias de

\footnotetext{
${ }^{17}$ Idem. Regulamento para a Casa de educação dos meninos pobres da Imperial Cidade de São Paulo.

${ }^{18}$ Para maior detalhamento ver Giglio, Celia Maria Benedicto. Uma genealogia de práticas educativas na Província de São Paulo: 1836-1876. São Paulo. Tese de Doutorado apresentada à Faculdade de Educação da Universidade de São Paulo - USP, 2001.
} 
Distrito, além da criação de um Conselho de Instrução Pública composto por 15 cidadãos nomeados pelo Governo. ${ }^{19}$

A existência da Inspetoria Geral da instrução permitiu o tratamento sistemático das questões que afetavam a instrução pública na província, buscou aperfeiçoar a estatística e produziu saberes a partir dessa organização, inaugurando um novo tipo de administração nesse ramo, que transitou de um modelo patrimonialista para um modelo burocrático-patrimonialista de administração. Essa transição se vincula em grande medida, à atuação direta do primeiro inspetor geral, Diogo de Mendonça Pinto, que permanece no posto até $1873 .^{20}$

Os relatórios destinados à Assembleia de São Paulo na segunda metade do século XIX assumiram características de maior rigor na confecção, maior detalhamento nos assuntos para prestar contas dos negócios públicos ao legislativo; passam a apresentar anexos e apêndices que servem de base para a construção do discurso central contido no relatório. Essa característica não é restrita ao campo da instrução pública; outros ramos da administração também instituem estruturas centrais de comando. Essa característica é evidência da especialização do Estado que vai diferenciando sua atuação e fixando, paulatinamente, um corpo de funcionários que garante a continuidade do trabalho das instituições, em contraposição à movimentação dos chefes políticos da província.

Nesse cenário, a Repartição da Instrução Pública e a atuação do Inspetor Geral Diogo de Mendonça ao longo de 21 anos pode dar significativos exemplos de conflitos entre políticas de Estado, baseadas na racionalidade da aplicação das leis, e políticas de Governo que se fazem por vezes acima das mesmas leis. Então, considerar a priori, que a política se encontrava fora da administração, produzindo nela apenas seu efeito, pode

\footnotetext{
${ }^{19}$ Relatório da Instrução Pública. Anexo ao Relatório apresentado à Assembleia Legislativa Provincial de São Paulo, pelo Presidente da Província, o Exmo. Sr. Dr. José Fernandes da Costa Pereira Júnior, em 2 de fevereiro de 1872.

${ }^{20}$ A partir de 1873 , assume a inspetoria geral, Francisco Aurélio de Souza Carvalho que permanece no cargo até 1885. O terceiro e último inspetor geral da Instrução Pública do Império foi Arthur Cesar Guimarães, que permaneceu no cargo até sua extinção, já durante a República, em 1896, conforme REIS FILHO, Cassemiro dos. Reforma Republicana do Ensino Público Paulista - Fase de Implantação - 1890-1896, Tese de doutorado, PUCSP, mimeo, 1974. Citado em Paris, M.L. A educação no Império: o jornal A Província de São Paulo, 1875-1889. Dissertação de Mestrado. FEUSP, 1980. p. 62.
} 
restringir a compreensão da política concorrente construída no interior da administração do Estado, neutralizando essa face da nascente burocracia no império. ${ }^{21}$

No plano mais geral de atuação da inspetoria, podemos afirmar que ela modela uma forma de administração que impacta práticas de governo na província, fazendo confrontar o poder político e o poder administrativo no interior do Estado.

O relatório inaugural produzido pelo inspetor geral em 10 de março de 1852, inicia a exposição apresentando um balanço que dá peso relativo ao juízo que "desqualifica de deplorável o estado da instrução pública em São Paulo". Considerando os esforços de instrução do povo acumulados desde século XVI na província, externa motivos suficientes para dar continuidade à obra da instrução pública vinculando-os à questão política do império. Afirma que "qualquer que seja a opinião política a que se acha o cidadão associado, chegue ele ao extremo do absolutismo ou da democracia, há de votar pelo desenvolvimento da inteligência: porque se a ignorância e barbaridade dos povos perpetua o despotismo, é também um instrumento poderoso de revoluções e nas sociedades de hoje todo poder vive ameaçado se o seu apoio não existe em adesões conscienciosas". Utilizando a forma governativa da Inglaterra como exemplo de estabilidade, afirma que o segredo está na força do hábito que coage o cidadão britânico a respeitar a Lei e a obedecer com veneração ao executor. "Pois bem, esses hábitos criam-se, atuando sobre a infância."22

O inspetor geral considera o ramo da instrução pública como parte do Direito Administrativo. Vejamos trecho citado em 1855, que indicia claramente este esforço de constituição da instrução como campo científico e do direito:

A instrução pública no sentido mais lato da palavra é a ciência, e em parte ramo do Direito Administrativo. Como ciência tem uma história e uma teoria. Sua história data do momento em que o primeiro homem sentiuse condenado ao aprendizado da existência. (...) Quanto à teoria a

\footnotetext{
${ }^{21}$ São muitos os estudos sobre o estado imperial e a burocracia patrimonial do Estado. Uma abordagem ampla sobre o tema pode ser consultada em, Bresser-Pereira, Luiz Carlos. Burocracia Pública na construção do Brasil. Ensaio. São Paulo, junho de 2008. Disponível em <www.bresserpereira.org.br/Books/LivroBurocraciaConstruçãoBrasil.6.pdf>.

${ }^{22}$ Relatório da Instrução Pública Provincial. Documentos que acompanham o Discurso com que o Ilustríssimo e Excelentíssimo Senhor Dr. José Thomaz Nabuco D’Araújo, Presidente da Província de São Paulo, $1^{\circ}$ de maio de 1852.
} 
instrução pública, como as mais ciências, tem editos cujas cortinas só aos adeptos é dado transpor. Cumpre surtir-se de inexaurível paciência, vergar-se a longo trabalho para penetrar nas instituições de ensino, tomar posse da experiência do passado, e grupar os princípios imutáveis, para os quais gravitam os ensaios. $(1855)^{23}$

Em 1856, abriu-se um Seminário Episcopal na província para suprir a formação de sacerdotes com o repúdio do inspetor geral sobre a forma com que o Seminário foi autorizado a funcionar, sem submissão às leis temporais. O repúdio registrado demonstra a construção de um espaço de poder da administração, referido ao governo das instituições e às leis, regulamentos e normas que deixava a salvo da inspeção o Seminário:

A proteção [do governo] porém tem um limite, não deve ser nunca tal que se transforme em ampla liberdade de proceder o Poder Episcopal como lhe aprouver. Para deixá-lo escapo das vistas do estado era mister que na educação do Clero os interesses temporais não se achassem mesclados aos da Igreja; que as noções inculcadas à infância no Seminário não repercutissem na associação política. Não há nação alguma, cujos exemplos devam ser consultados, onde seja permitido a um Bispo a instalação de uma casa de instrução com a inteira faculdade de matricular e ensinar como for de sua vontade em subordinação a visita e inspeção de quem quer que seja exceto a sua. Isto não é só inconveniência e perigo, é infração indisputável do nosso Direito. ${ }^{24}$

Avocando a Constituição do Império, o Inspetor introduz, no discurso, o conflito existente entre dois modos de governar: a partir das leis, normas e regras escritas, que recaíam sobre todos igualmente e um outro modo, que mobilizava dispositivos invisíveis para gerir as diferenças de tratamento dadas às instituições.

O Seminário Episcopal é de criação do respeitável prelado, não de Lei alguma; e como a legislação Provincial sujeita todas as Instituições de ensino existentes na Província à superintendência e fiscalização do Governo pelos Agentes, não pode o Seminário subsistir isento delas sem violação da Lei. Ora é sabido, e repito o que já uma vez o disse: nada mais

\footnotetext{
${ }^{23}$ Relatório da Instrução Pública da Província no corrente ano. Diogo de Mendonça Pinto, Inspetor Geral da Instrução Pública. 31 de dezembro de 1854.

${ }^{24}$ Relatório da Instrução Pública. Documentos com que o Ilustríssimo e Exmo. Presidente da Província de S. Paulo instruiu o Relatório de abertura da Assembleia Legislativa Provincial, no dia 2 de fevereiro de 1858.
} 
funesto que o exemplo do desrespeito e violação da Lei que parte dos altos Funcionários da Nação. Reclamo pois com insistência pela intervenção do Governo na parte que lhe compete. E se há alguma consideração atendível que autorize a plena independência em que vive o Seminário o que não creio, pelo menos reformando-se a Instrução Pública, se decrete que ele fica salvo da ingerência da Autoridade, abrase uma exceção expressa ao preceito legal em favor das casas de instrução e educação, que o Chefe da Igreja paulistana fundar. Deixar em pé uma lei, na qual se acha ele compreendido, e ao mesmo tempo consentir na inobservância, é ato que não tem explicação. As Leis são feitas para que sejam obedecidas: se alguém se coloca fora delas, se convém conceder-lhe esse privilégio, é preferível revogá-las. A ninguém deve ser autorizado o direito impunemente de infringi-las. Nem conheço Poder algum no Estado autorizado a tanto. ${ }^{25}$

O clero constitui-se em problema político para o Estado, cujo foco residia nos comportamentos de um corpo de sacerdotes que se afastava das regras estabelecidas entre a Igreja e o Estado, nas desobediências e insubordinação dos primeiros ao poder temporal do Estado.

\section{A prática da inspeção das escolas de primeiras letras na Província na segunda metade do século XIX}

A fala do Inspetor Geral localiza como causas do estado deplorável de algumas escolas na Província, a inaptidão dos mestres e a independência com que atuavam, livres de qualquer inspeção. A missão, portanto, era a de uma fiscalização eficaz sobre as práticas dos mestres, a orientação sobre os melhores métodos de ensino a serem praticados e a regularidade necessária ao funcionamento da instituição.

A vastidão dos Distritos impôs dificuldades para a vigilância sistemática, pois segundo o inspetor geral "alguns havia que exigiam do inspetor de distrito, viajar léguas para a visita das escolas, o que causava repugnância em muitas das pessoas habilitadas". O regulamento de 1851, para além de instituir uma "arquitetura" de vigilância sobre as escolas públicas, em especial as escolas de primeiras letras, obrigou a presença do Estado na iniciativa particular, regulamentando práticas antes completamente distantes do campo de visibilidade do Estado. Visto que a instrução era estratégica para a manutenção

\footnotetext{
${ }^{25}$ Idem.
} 
do regime e da moralidade pública, o ensino particular, livre de regulação pelo Estado, surgia no discurso como grave perigo ao país, como indústria aberta à livre concorrência.

\begin{abstract}
O ensino particular no país era uma indústria aberta a livre concorrência; um nacional, ou estrangeiro soubesse ou não a nossa língua, qualquer que fosse sua aptidão profissional, a moralidade de sua vida e as opiniões políticas e religiosas a que se achasse votado, fundava uma casa de instrução, sem receio de que nenhuma formalidade previa the fosse reclamada, nenhuma intervenção do poder tivesse de desacomodá-lo. ${ }^{26}$
\end{abstract}

As primeiras providências indicadas pela nova Repartição apontavam como essencial para arrancar as escolas de primeiras letras de seu abatimento, a organização de um regulamento policial e econômico das aulas e, de um outro regulamento, que deveria reger os inspetores de distrito para a realização de seus deveres. Quanto ao primeiro regulamento, destinado a disciplinar o funcionamento das escolas, o inspetor geral ressaltou:

Semelhante regimento em cadeira alguma se ostenta tão inquestionavelmente necessário como na de $1^{\text {a }}$ letras. $O$ modo prático do ensino, o método a adotar, os compêndios e traslados preferíveis, a duração diária do exercício, a disciplina escolástica, os meios de se obter fiel inspeção, sobretudo na parte relativa ao número de alunos que as frequenta e o programa dos exames, enfim toda a política e economia ainda está por determinar-se. Saber-se deste fato é conhecer-se a razão porque não tem sido a instrução elementar mais rapidamente progressiva. $^{27}$

O papel dos inspetores de Distrito seria o de um olhar atento, sistemático e regrado sobre as instituições; o meio de controle destas observações seria feito através de relatórios trimestrais a serem enviados à inspetoria geral. O "policiamento" sobre os procedimentos profissionais e morais dos professores, e sobre a frequência dos alunos, era uma das principais tarefas dos inspetores cabendo-lhes impor aos professores o ônus de enviar uma relação dos alunos, que compareceram durante a semana e dos que

\footnotetext{
${ }^{26}$ Idem.

${ }^{27}$ Idem.
} 
faltaram e em que dias, para que, a vista dela, pudessem os inspetores fiscalizar, o que obrigada a chamada diária dos alunos, feita pelos professores. ${ }^{28}$

As incumbências dadas aos inspetores de distrito, no entanto, mostram-se rapidamente irrealizáveis. Em 1853, o presidente dá notícias sobre a necessidade da divisão da província em círculos literários e em cada um deles, nomear um inspetor com atribuições mais amplas que as do inspetor de distrito. Temos aqui, com maior vigor, o movimento de ordenação da inspeção, construindo uma espécie de hierarquia que configura a rede de informantes, submetidos eles próprios à fiscalização. Já em 1854, o inspetor geral informa que nem todos os inspetores cumprem suas responsabilidades e nem todos demonstram a necessária aptidão para a tarefa, sendo, alguns deles, apontados como indolentes.

Nossas circunstâncias nos privam do pessoal preciso, sirvamo-nos de um mecanismo de administração que sem empregar pessoal menos numeroso, evite as falhas do atual. Será impraticável? Há muita gente possuída de boa vontade, mas a quem falta a cultura da inteligência; temos pela Província espalhados homens instruídos, mas em pequeno número; divida-se o serviço e confie-se a estes tudo quanto na inspeção há de científico e mais incômodo e o resto abandone-se àqueles. Ponhase assim em contribuição a boa vontade de muitos e o saber de poucos. Tal é o pensamento do sistema de governo do ensino proposto no último Relatório. $(. . .)^{29}$

A inspeção das escolas de primeiras letras teve importante papel para dar visibilidade ao comportamento das famílias, o que possibilitou novas estratégias de interferência do Estado em relação ao governo das escolas, para alterar o estado da instrução pública, incluindo-se aí a longa discussão sobre a obrigatoriedade da instrução elementar. Se a atuação dos inspetores de Distrito não atendeu plenamente as finalidades de alavancar as soluções para arrancar a instrução pública de seu estado não lisonjeiro, ela permitiu povoar os discursos com novas temáticas, antes submersas nos

\footnotetext{
${ }^{28}$ Idem. A chamada diária dos alunos, como prática obrigatória dos afazeres do mestre, passa a compor parte de uma série de outros controles que serão exercidos do exterior sobre suas práticas e comportamentos, a partir de uma série de regramentos que são editados ao longo do tempo.

${ }^{29}$ Relatório da instrução Pública da Província no corrente ano. Diogo de Mendonça Pinto, Inspetor Geral da Instrução Pública. 31 de dezembro de 1854. Documentos com que o llustríssimo e Excelentíssimo Senhor Dr. José Antonio Saraiva, Presidente da Província de S. Paulo, 15 de fevereiro de 1855.
} 
julgamentos elaborados de modo genérico, a partir das estatísticas que envolviam o número de alunos matriculados e frequentes.

Entre as causas que explicavam o estado não lisonjeiro da instrução pública, a partir de 1860, estarão novos e velhos argumentos: a "liberdade de ação dos mestres" cede espaço para crítica à ação dos inspetores parciais, sobre seus comportamentos e a necessidade de formação dos professores, de habilitá-los com saberes especiais para ensinar o conhecimento teórico e prático sobre os métodos de ensino.

São três as causas primordiais do mal: a falta de preparação dos Mestres para a laboriosa e difícil profissão, a que se votam, - a ausência de processos de ensino adaptados aos fins da instrução primária, - e a funesta liberdade concedida aos chefes de famílias de retirar das escolas seus filhos quando lhes apraz. Nossa civilização tal qual é deve muito às nossas escolas mal montadas como se acham; para que porém cheguem à altura de seu destino, urge fundar uma escola normal, e decretar o regime interno das escolas, no qual os Professores encontrem os métodos que devem pôr em prática e a segurança de que os discípulos não se despedirão enquanto seus conhecimentos não tomarem a extensão e elevação que a lei recomenda. Mas não nos iludamos, todas as medidas se baldarão desde que o magistério primário não se veja acoroçoado e remunerado a ponto de se tornar na sociedade posição cobiçada $(. . .)^{30}$

No ano de 1861, o prognóstico lançado pelo Relatório do Inspetor é o de que mais de um terço das pessoas da Província são analfabetas e numerosas as que, nos dois terços restantes, sabem apenas ler mal e garatujar o próprio nome. Para modificar o quadro destes deserdados da instrução elementar, indica mais uma vez as providências necessárias: disseminar na província boas escolas e meios coercitivos para que os cidadãos de todas as classes recebam as primeiras letras até serem dispensados pelo mestre; disso resulta a necessidade de estabelecer um regime interno, a escolha de métodos de ensino, a adoção de bons compêndios, a concessão de prédios para estabelecer as escolas, a distribuição dos materiais e mobília necessários, excelentes mestres e zelosos agentes do governo que as inspecionem:

\footnotetext{
${ }^{30}$ Idem.
} 
E não há tais Mestres e Inspetores se estes não são retribuídos, e se aqueles se acham abandonados à vida inglória e sem futuro, mal paga, e sobretudo se não se preparam em uma instituição onde se lhes ministrem os conhecimentos precisos e se verifique sua vocação ao laborioso exercício do magistério. Onde falte tudo isso que dizer da instrução pública? ${ }^{31}$

As falas do inspetor, paulatinamente desenham a necessidade de um aparato administrativo, hierarquizado, distinto do modelo que se apoiou na ação de agentes não pertencentes ao quadro da administração e com as qualidades necessárias à tarefa. Desse modo, a inspeção da instrução pública passa a tomar importância nos relatos dos presidentes a fim de induzir o legislativo à compreensão dessa necessidade. Em 1865, o relatório do presidente, tendo como modelo de inspeção aquele executado na França, ressalta:

O ensino para produzir os seus efeitos necessita da inspeção. A inspeção é o governo da instrução. A inspeção oferece dois aspectos; ela é ordinária ou extraordinária. A ordinária subdivide-se em cotidiana, e é indeterminada ou imprevista. A inspeção cotidiana chama-se vigilância. Ela é própria das autoridades locais que vivem em contato com a escola, e exerce sua intervenção todos os dias. $A$ inspeção indeterminada ou imprevista deve ser exercitada com o fim de fortificar a vigilância das autoridades locais, despertar o zelo dos professores, uniformizar o ensino, e representar o pensamento que o preside, manifestado pela autoridade central que dirige o governo da instrução. Assim organizada a inspeção, sem a qual eu não compreendo a possibilidade de auferir vantagens e proveito da instrução, cumpre observar que assim a vigilância, como a inspeção propriamente dita demanda pessoas habilitadas. ${ }^{32}$

Num balanço sobre o estado da instrução pública na província, feito pelo presidente em 1866, denuncia o seu péssimo estado. Ao considerar a necessidade de reformas, recupera elementos tais como a inutilidade de mudanças parciais, a necessidade de habilitação do professorado e efetividade da inspeção. Considerando os

\footnotetext{
${ }^{31}$ Relatório da Inspetoria Geral da Instrução Pública em 31 de dezembro de 1860. Anexo ao Discurso do Excelentíssimo Senhor Conselheiro Antonio José Henriques Presidente da Província de São Paulo, 2 de março de 1861.

${ }^{32}$ Relatório apresentado à Assembleia Legislativa Provincial de São Paulo, no dia 2 de fevereiro de 1865, pelo Presidente Conselheiro João Chrispinianno Soares.
} 
elevados custos para tanto, questiona "se unicamente a província e não também a nação deve suportar esse pesado ônus; e se o ato adicional isentou ao poder geral desta obrigação". ${ }^{33}$ Dois anos após esse balanço, a Lei provincial n ???, de 15 de abril de 1868, reforma o ensino primário e é editado novo Regulamento para a Instrução Pública em 17 de abril do mesmo ano; nele, os dispositivos de controle se aperfeiçoam, distribuem-se as responsabilidades de modo cada vez mais minucioso, complementando a disposição desta rede de vigilância acompanhada de medidas para o regramento do ensino e a admissão de professores.

O regulamento institui os Presidentes das Câmaras Municipais como os inspetores das escolas em seus municípios, incumbindo-lhes, conforme o Art. 14 do regulamento: “ $\S 1^{\circ}$ Velar em bem de que os professores cumpram seus deveres. $\S 2^{\circ}$ Dirigir aos inspetores de distrito todas as ordens que sejam a eles expedidas pelo inspetor geral, e deles receber todas as comunicações e informações, e transmiti-las ao mesmo inspetor geral. $\$ 3^{\circ}$ Propor a este as medidas que forem convenientes para a boa marcha do ensino em seus municípios”. Criava-se uma espécie de rede de inspeção superior, à qual estariam submetidos os Inspetores de Distrito. ${ }^{34}$

Em 1872, a legislação indicava que a inspeção ordinária do ensino cabia ao Inspetor Geral, chefe da repartição que cuida especialmente deste ramo de serviço; aos Inspetores de Distritos, não estipendiados, e aos Presidentes das Câmaras Municipais. Para a inspeção extraordinária, a Diretoria da Instrução estava autorizada a nomear comissões também voluntárias, mas que ficavam sujeitas, como os Inspetores Locais, a multas no caso de omissão ou falta de cumprimento de deveres. Esta "arquitetura” de vigilância, no entanto, mostra-se pura ruína, sendo o principal argumento o fato de não haver retribuição pelos serviços. A ausência de envio de informações, dos mapas de frequência de alunos, continuou a ser apontada pelo inspetor geral até sua aposentadoria.

Para o que há de incompleto e deficiente na inspeção local seria corretivo, em parte ao menos, a inspeção extraordinária, exercida por

\footnotetext{
${ }^{33}$ Relatório apresentado à Assembleia Legislativa Provincial de S. Paulo, no dia 3 de fevereiro de 1866, pelo Presidente da mesma Província, o Dr. João da Silva Carrão. Conselheiro.

${ }^{34}$ Regulamento $n^{\circ} 4$ Instrução Pública. Anexo ao Relatório apresentado à Assembleia Provincial de S. Paulo, no dia 2 de fevereiro de 1868, pelo Presidente, O Conselheiro Joaquim Saldanha Marinho.
} 
cidadãos de confiança da administração, que inesperadamente visitassem as escolas.

Mas aqui sobressai o defeito do sistema adotado. Como encontrar facilmente quem, de boa vontade, com ânimo resoluto, se incumba desse penoso serviço, percorrendo extensa circunscrição territorial, fazendo viagens (...) sindicando do procedimento dos professores(...) Organizado o ensino pedagógico, adotado um sistema de inspeção que, em último caso, não deixe tudo à boa vontade dos próprios professores, devem ainda concorrer outras medidas complementares do sistema geral da administração em referência a este ramo de serviço. ${ }^{35}$

O modelo de inspeção forjado no império acenou para um ambiente em que os mestres deveriam estar submetidos à vigilância dos inspetores parciais; estes estariam sob a inspeção dos Presidentes das Câmaras, e todos deveriam submeter-se ao Inspetor Geral que, por sua vez, se submetia diretamente ao Presidente numa rede que possibilitaria alimentar o centro com informações "verdadeiras", vinculando-os todos a uma trama de regulamentações que pretendiam assegurar os vitais interesses da sociedade, para a garantia da ordem e da liberdade. Esta pirâmide de olhares, ordens, prescrições, registros, no entanto, não garantiu a sujeição à hierarquia desejada, dando visibilidade a um universo de contrapoderes, atuando dentro e fora do Estado, ora transgredindo suas ordenações e códigos, ora apoiando-se neles para conformar múltiplas estratégias de dominação.

O último relatório do inspetor Diogo de Mendonça, publicado como anexo ao relatório do presidente, em 1873, se constitui num libelo que narra os embates sem fim para o desenvolvimento da instrução na província. As grandes dificuldades para fazer realizar as prescrições legais e as normas, a desobediência à lei de parte do próprio governo e o uso imoral de recursos destinados ao melhoramento da instrução na província permanecem nos relatos dos anos seguintes. As falas dos agentes do Estado, tais como as do Diretor da Casa de Correção, que permanece na administração por 18 anos, a fala do Inspetor da Instrução Pública da Província, que permanece por 21 anos administrando a Repartição, contrasta com as falas que ocupam o lugar de poder do Presidente, quase itinerante, cuja permanência por vezes é efêmera. Haidar (1972 p. 29), a propósito do tratamento das políticas de descentralização do ensino no Brasil imperial e

\footnotetext{
35 Relatório apresentado à Assembleia Legislativa Provincial de São Paulo, pelo Presidente da Província Sr. Dr. José Fernandes da Costa Pereira Júnior, em 2 de fevereiro de 1872.
} 
às dificuldades de implantação das políticas em instrução pública, faz referência aos Presidentes de Província:

Pouco puderam fazer tais governos "de uma estação" no campo da instrução pública; a instabilidade dos Presidentes 'beduínos', como os apelidaria Nabuco, as preocupações predominantemente políticas e politiqueiras das assembleias locais e a insuficiência dos recursos financeiros criavam um clima totalmente impropício à execução das reformas que se sucediam vertiginosamente mas que ficavam no papel. (Haidar,1972, p. 29)

Em grande medida, os constrangimentos enfrentados na direção da inspetoria geral da instrução pública estão vinculados a essa quase itinerância dos presidentes que fundam um eterno recomeço na condução das políticas locais. Sendo eles de nomeação do imperador, localizamos na prática de efemeridade ou de rotatividade de presidentes, um dispositivo complexo que garante a centralização da política, na medida em que os presidentes atuam sobre um legado de fidelidades que só a eles compete como agentes representando a extensão do poder imperial.

\section{Conclusão}

Dando centralidade à inspeção, o exame dos relatórios dos presidentes e dos Inspetores até 1876, permite concluir que a consolidação da inspeção como fórmula de civilização é bem-sucedida.

No plano restrito de ação da inspetoria geral sobre as escolas e instituições, podemos afirmar que, ainda que uma rede de inspeção se institua com dificuldades, a existência de inspeção central modifica as práticas de governo das instituições educativas com a produção intensa de regulação, aliada à vinculação entre normas escritas e observação direta. Desse modo, destacamos a característica plástica dessa inspeção que define formas distintas para atuar sobre as instituições cerradas e sobre a atividade de instrução dispersa nas escolas de primeiras letras, talvez seu maior desafio. 
A inspeção precipitou a visibilidade das condições de trabalho dos mestres, das instalações de funcionamento das escolas, os salários mesquinhos, as contradições na edição de leis, as disputas políticas. Este olhar sistemático sobre a atividade das escolas implicou ainda no contínuo regramento e na consolidação do poder administrativo na província.

\section{Referências}

BRESSER-PEREIRA, Luiz Carlos. Burocracia Pública na construção do Brasil. Ensaio. São Paulo, junho de 2008. Disponível em <www.bresserpereira.org.br/Books/LivroBurocraciaConstruçãoBrasil.6.pdf>. Acesso em 4 de novembro de 2016.

BRASIL. Lei de 20 de outubro de 1823. Dá nova forma aos Governos das Províncias, criando para cada uma delas um Presidente e Conselho. Disponível em <http://www2.camara.leg.br/legin/fed/lei_sn/anterioresa1824/lei-40978-20-outubro-1823574639-publicacaooriginal-97736-pe.html>. Acesso em 4 de novembro de 2016.

BRASIL. Constituição Política do Império do Brasil (de 25 de março de 1824). Constituição Política do Império do Brasil, elaborada por um Conselho de Estado e outorgada pelo Imperador D. Pedro I, em 25.03.1824. Carta de Lei de 25 de Março de 1824. Manda observar a Constituição Política do Império, oferecida e jurada por Sua Majestade o Imperador. Disponível em <http://www.planalto.gov.br/ccivil_03/constituicao/constituicao24.htm>. Acesso em 4 de novembro de 2016.

BRASIL. Lei $\mathbf{n}^{\circ} 16$ de 12 de agosto de 1834. Faz algumas alterações e adições à Constituição Política do Império, nos termos da Lei de 12 de Outubro de 1832. Disponível em: <http://www.planalto.gov.br/ccivil_03/leis/lim/LIM16.htm>. Acesso em 4 de novembro de 2016.

CALIMAN Auro Augusto (Coord.). Legislativo Paulista: parlamentares, 1835-1999. 2. ed. São Paulo: Imprensa Oficial, 1999.

CHARTIER, Roger. A história cultural: entre práticas e representações. Lisboa: DIFEL/ Rio de Janeiro: Bertrand Brasil, 1990. 
FOUCAULT, Michel. La verdad y las formas jurídicas. México: Gedisa, 1983.

GIGLIO, Celia Maria Benedicto. Uma genealogia de práticas educativas na Província de São Paulo: 1836-1876. 2001. Tese (Doutorado em 2001) - Universidade de São Paulo, Faculdade de Educação, São Paulo, 2001.

HAIDAR, Maria de Lourdes Mariotto. O ensino secundário no Império Brasileiro. São Paulo: EDUSP, Editorial Grijalbo Ltda., 1972.

OLIVEIRA, Carlos Eduardo França de. Entre o local e o provincial: os Conselhos Gerais de Província e as Câmaras Municipais, São Paulo e Minas Gerais (1828-1834). Almanack. Guarulhos, n. 09, p. 92-102, abril de 2015. Disponível em: <http://www.scielo.br/pdf/alm/n9/2236-4633-alm-9-00092.pdf>. Acesso em 4 de novembro de 2016

PARIS, Mary Lu. A educação no Império: o jornal A Província de São Paulo, 1875-1889. 1980. Dissertação (Mestrado em 1980) - FEUSP, São Paulo, 1980.

SILVA, Wellington Barbosa da. "Uma autoridade na porta das casas": os inspetores de quarteirão e o policiamento no Recife do século XIX (1830-1850). SAECULUM [17] p. 27-41; João Pessoa, jul/dez. 2007. Disponível em:

<http://www.pm.al.gov.br/intra/downloads/bc_policial/pol_o6.pdf >. Acesso em 4 de novembro de 2016.

SÃO PAULO. Lei n 34 de 16 de março de 1846. Assembleia Legislativa provincial. Disponível em <http://www.al.sp.gov.br/repositorio/legislacao/lei/1846/lei-3416.03.1846.html>. Acesso em 4 de novembro de 2016.

SÃO PAULO. Discurso recitado pelo Exmo. presidente, Manoel Machado Nunes no dia 7 de janeiro de 1840 por ocasião da abertura da Assembleia Legislativa Provincial. S. Paulo, Typ. de Costa Silveira, 1840.

SÃO PAULO. Discurso Recitado pelo Exmo. Presidente José Carlos Pereira d'Almeida Torres, 7.1.1843, por ocasião da abertura da Assembleia Legislativa da Província de S. Paulo. Typografia do Governo arrendada por Silva Sobral 1843.

SÃO PAULO. Discurso recitado pelo Exmo. presidente, Manuel Felisardo de Souza e Mello, no dia 7 de janeiro de 1844, por ocasião da abertura da Assembla Legislativa da província de S. Paulo. S. Paulo, Typ. do Governo, 1844.

SÃO PAULO. Relatório apresentado pelo Exmo. Presidente Manuel da Fonseca Lima e Silva no dia 7 de janeiro de 1845 por ocasião da abertura da Assembleia Legislativa da Província de São Paulo. Typografia do Governo arrendada por Silva Sobral. 1845.

SÃO PAULO. Discurso com que o llustríssimo e Excelentíssimo Senhor Dr. José Thomaz Nabuco D’Araújo, Presidente da Província de São Paulo, abriu a Assembleia Legislativa Provincial, no $1^{\circ}$ de maio de 1852. 
SÃO PAULO. Relatório da Instrução Pública da Província no corrente ano. Diogo de Mendonça Pinto, Inspetor Geral da Instrução Pública. 31 de dezembro de 1854.

SÃO PAULO. Relatório da instrução Pública da Província no corrente ano. Diogo de Mendonça Pinto, Inspetor Geral da Instrução Pública. 31 de dezembro de 1854. Documentos com que o Ilustríssimo e Excelentíssimo Senhor Dr. José Antonio Saraiva, Presidente da Província de S. Paulo, instruiu o Relatório da abertura Assembleia Legislativa Provincial no dia 15 de fevereiro de 1855.

SÃO PAULO. Relatório da Instrução Pública. Documentos com que o llustríssimo e Excelentíssimo Senhor Senador José Joaquim Fernandes Torres, Presidente da Província de S. Paulo, instruiu o Relatório de abertura da Assembleia Legislativa Provincial, no dia 2 de fevereiro de 1858.

SÃO PAULO. Relatório da Inspetoria Geral da Instrução Pública em 31 de dezembro de 1860. Anexo ao Discurso com que o llustríssimo e Excelentíssimo Senhor Conselheiro Antonio José Henriques Presidente da Província de São Paulo, abriu a Assembleia Legislativa Provincial no dia 2 de março de 1861.

SÃO PAULO. Relatório apresentado à Assembleia Legislativa Provincial de São Paulo, na Segunda sessão da Décima Quinta legislatura no dia 2 de fevereiro de 1865 pelo Presidente da mesma Província O Conselheiro João Chrispinianno Soares.

SÃO PAULO. Relatório apresentado a Assembleia Legislativa Provincial de S. Paulo, na $1^{\text {a }}$ sessão da Décima Sexta Legislatura, no dia 3 de fevereiro de 1866, pelo Presidente da mesma Província, o Dr. João da Silva Carrão. Conselheiro.

SÃO PAULO. Relatório apresentado à Assembleia Provincial de S. Paulo, na Primeira sessão da Décima oitava legislatura, no dia 2 de fevereiro de 1868, pelo Presidente, 0 Conselheiro Joaquim Saldanha Marinho.

SÃO PAULO. Relatório da Instrução Pública. Anexo ao Relatório apresentado à Assembleia Legislativa Provincial de São Paulo, pelo Presidente da Província, o Exmo. Sr. Dr. José Fernandes da Costa Pereira Júnior, em 2 de fevereiro de 1872.

Recebido em: 05/01/2017 Aprovado em: 11/02/2016

Universidade do Estado de Santa Catarina - UDESC

Programa de Pós-Graduação em Educação - PPGE

Revista Linhas

Volume 18 - Número 36 - Ano 2017 revistalinhas@gmail.com 